\title{
MICROECONOMIC ANALYSIS OF THE CROATIAN INFORMATION AND COMMUNICATION SECTOR
}

\author{
HERCEG, T[omislav]; SKUFLIC, L[orena] \& RKMAN, P[etra]
}

\begin{abstract}
In this paper Croatian Information and communication technologies (ICT) sector is analyzed in the period from 2008-2010. The aim of this analysis was to analyze whether capital and labour in this sector have been used with allocation efficiency. A microeconomic approach was used to determine the level of the allocation efficiency. The foundation of this analysis lies in the econometric estimation of the Croatian ICT sector's production function, assuming the CobbDouglas function. The obtained results show that, keeping the costs of production the same, an $8 \%$ increase in the ICT production could have been made if ICT companies have used more capital and $10 \%$ less labour.
\end{abstract}

Keywords: Croatian ICT sector, Cobb-Douglas production function, allocation efficiency, isoquant, isocost

\section{INTRODUCTION}

The power of economic competitiveness of a country depends, among others, upon the productivity of its information and communication technologies (ICT) sector, since science, technology and innovation have become key factors contributing to economic growth in both developed and developing economies. While contribution of ICT to productivity and economic growth has been acknowledged, it is important to differentiate contributions from ICT production and ICT use. The importance of ICT use is expressed by the lack of universally accepted definition of ICT. It cannot be formed since concepts, methods and applications involved in ICT constantly evolve on an almost daily basis, which makes it difficult to keep up with the changes.

There are numerous advandatages of the ICT sector: little investments, high yields, high human capital requirements which improves the educational attainment of the labour, high participation of the labour (which is highly important in times of the unemployment problem) and finally, it is very export friendly without any transactional costs. For instance, an Indian employee is able to work for a British call-centre, and a Croatian programmer builds software for an American company. These workers earn much larger salaries than the average salary in her domestic economy, while employer pays less than it would pay in its own country.

In the light of the omnipresent and a long-lasting worldwide crisis it is crucial to find an export-oriented, low-investment, labour intensive businesses. This type of industry is the ICT sector. However, the main prerequisite for this business are the highly educated ICT experts. Hence the government should promote ICT higher education.

In this paper an ICT production in Croatia is analyzed. Using a microeconomic theory, this paper tries to show the current situation in the Croatian ICT. Firstly, a production function will be estimated. It will be the foundation for the analysis of the efficiency in the allocation of the inputs (capital and labour). It will give the answer to the question whether the efficiency is low or high, and the ways how to improve it without additional costs.

\section{STATISTICAL OVERVIEW OF ICT IN CROATIA}

ICT sector is one of the fastest growing sectors of the economy; not only does its share in GDP increase in most of the world countries, but also it uses a little capital investments and employs highly educated workforce which causes an increase in a demand for a skilled labour. It then causes an increase of demand for higher education which, in return increases the education level of the nation.

According to the most recent research of the World Economic Forum (WEF) on ICT Croatia is ranked 45th out of 142 countries. ICT sector account for $11 \%$ of the Croatian gross domestic product with total revenue of

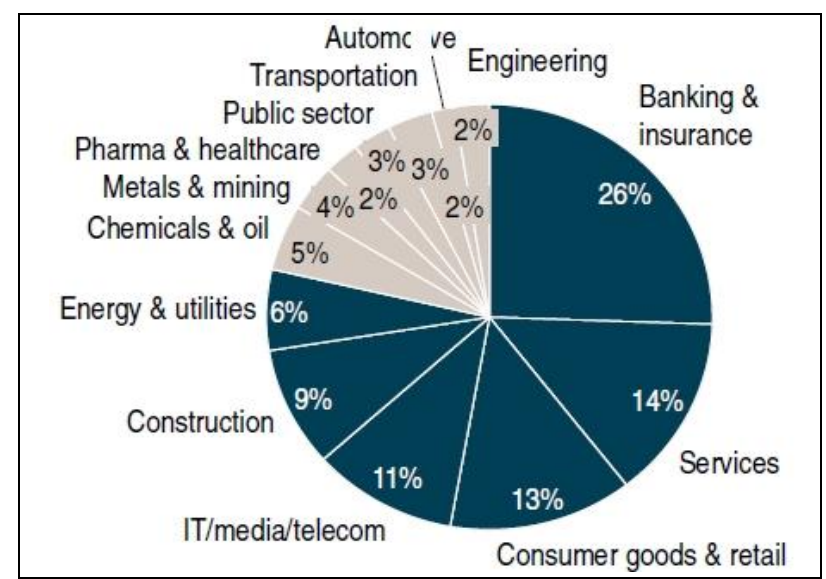

Fig. 1. Segmentation of Croatian market

source: Roland Berger Strategy Consultants, 2010

HRK Bill. 27.65 in the year 2010, in which Information Technologies (IT) has 40,5\%, with 1822 companies and 12671 workers [1]. 
The liberalisation in the telecommunications market in Croatia started in January 2003. It led to 261 companies in 2010, with telecom operators as the most important market segment.

\section{PRODUCTION FUNCTION ESTIMATION}

The first step for the analysis is the production function estimation. An econometric approach was used. It is commonly assumed that the production depends upon capital and labour [2],[3],[4]. The data for the production function estimation are the ICT sector data is the panel data set with 39 observations: three years (2008, 2009 and 2010) and thirteen subdivisions of the $\mathbf{J}$ segment of the GDP according to the latest NACE review (NACE is the international standard for the national accounting, corresponding to the Croatian NKD 2007). The data needed to estimate a production function for Croatian Information and communication technologies sector is obtained from Croatian Chamber of Commerce. The aggregation of the subsectors is up to the third digit. The names of these categories, along with the NACE codes, are given in the Table 1.

The capital for the analysis is calculated from the data for long-term assets according to [6] and [7], and the data for labour is calculated from the number of workers, but corrected according to the [8] and [9].The estimated production function is the most common, Cobb Douglas production function. Although it has some strong assumptions [10], like unit elasticity of substitution [11], it is still better than all the alternatives (translog, CES, etc.) due to its simplicity and the ability of the linearization [12],[13]. Hence the assumed production function is:

$$
Y=A K^{\kappa} L^{\lambda}
$$

A linearized model is as follows:

$$
\ln Y=\beta_{0}+\beta_{1} \ln K+\beta_{2} \ln L+u_{t}
$$

\begin{tabular}{|c|l|}
\hline $\begin{array}{c}\text { NACE } \\
\text { code }\end{array}$ & \multicolumn{1}{|c|}{\begin{tabular}{c}
\multicolumn{1}{c|}{ NACE categories for the Information and } \\
Communication [11]
\end{tabular}} \\
\hline J581 & $\begin{array}{l}\text { Publishing of books, periodicals and other publishing } \\
\text { activities }\end{array}$ \\
\hline J582 & Software publishing \\
\hline J591 & $\begin{array}{l}\text { Motion picture, video and television programme } \\
\text { activities }\end{array}$ \\
\hline J592 & Sound recording and music publishing activities \\
\hline J601 & Radio broadcasting \\
\hline J602 & Television programming and broadcasting activities \\
\hline J611 & Wired telecommunications activities \\
\hline J612 & Wireless telecommunications activities \\
\hline J613 & Satellite telecommunications activities \\
\hline J619 & Other telecommunications activities \\
\hline J620 & $\begin{array}{l}\text { Computer programming, consultancy and related } \\
\text { activities }\end{array}$ \\
\hline J631 & $\begin{array}{l}\text { Data processing, hosting and related activities; web } \\
\text { portals }\end{array}$ \\
\hline J639 & Other information service activities \\
\hline
\end{tabular}

Tab. 1. NACE categories for the ICT sector

A general least squares method is used for the regression parameters estimation [14],[15]. The econometric software that was used in the analysis is STATA.

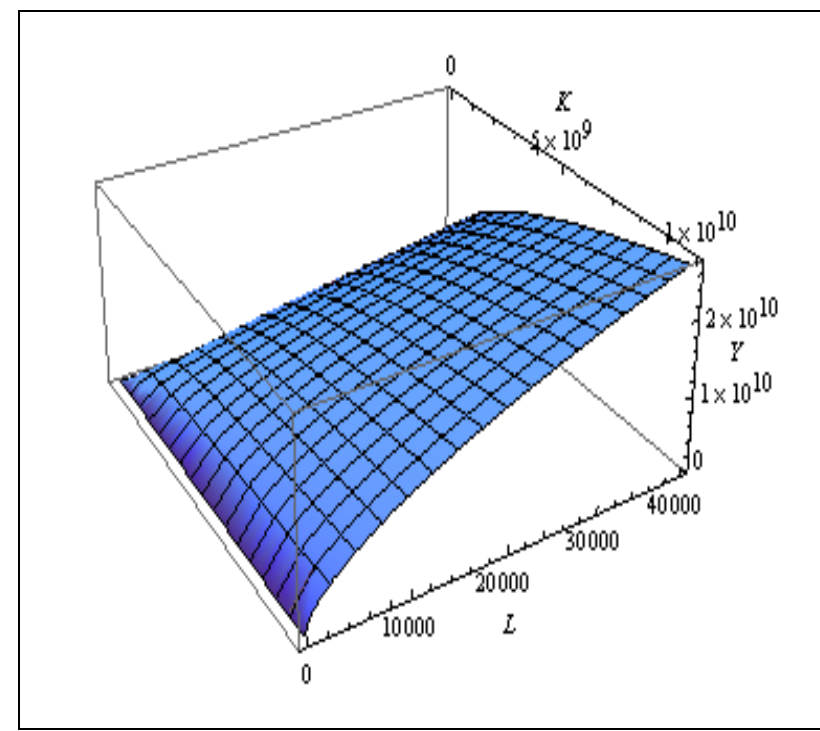

Fig. 1. The estimated production function for Croatian ICT in the period 2008-2010

In the form (1) the model was not adequate, hence a transformation $\kappa=\lambda$ was made. Some authors [16] suggest that total factor productivity (TFP, or A) should be decomposed into a polynomial [17] or exponential form with trend variable [18], but the results show that time is not significant in the model. The obtained results are:

$$
\begin{aligned}
\ln \widehat{Y}= & 8.5891+0.3961 \ln K+0.5955 \ln L \\
& (0.0000)(0.0000)
\end{aligned}
$$

In the brackets bellow the parameters one can see the $p$ values of the $t$ test. This model has passed all the required tests and is qualified for further application. A functional form of these results are given with (4) and drawn in the Figure 1.

$$
\hat{Y}=5372.9 K^{0.396} L^{0.596}
$$

Using an Euler theorem [19] it can be seen that the $\kappa$ and $\lambda$ correspond to the input elasticities, which imply that the marginal product of labour is greater than the marginal product of capital. It can also be seen graphically from the Figure 2 .

The Figure 2 depicts the layer curves of the production function (4). On this graph the capital is denoted on the $y$ axis and labour on the $x$ axis. The layer curves, which are called the isoquants in the case of the production function, connect all the combinations of inputs that represent the same amount of production. It can be seen that the isoquants lean towards the $y$ axis, which corresponds to the labour input. Hence, the labour is more productive than capital since production expansion curve leans towards the labour axis. 


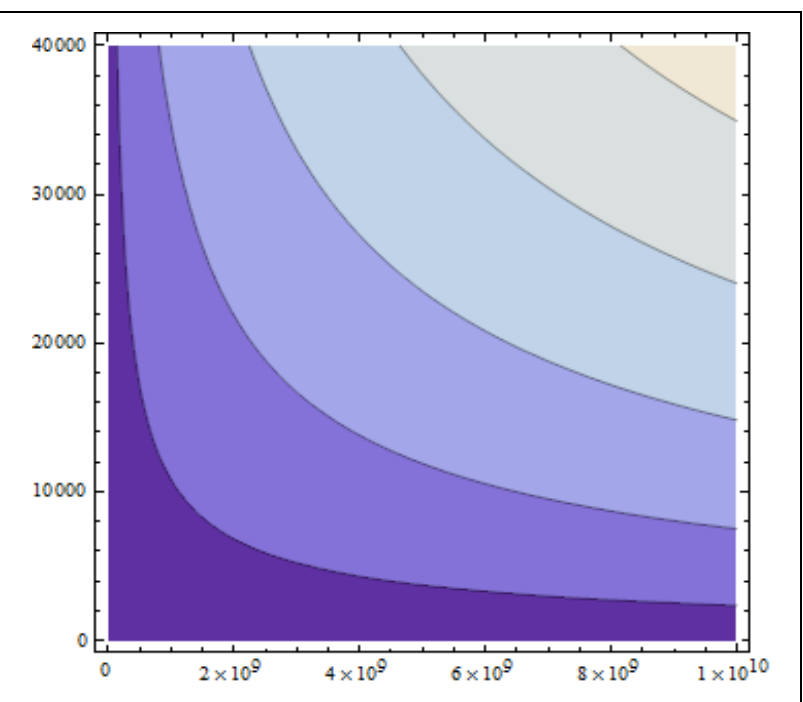

Fig. 2. Layer curves of the production function for Croatian ICT in the period 2008-2010 (labour on the $y$ axis)

It is the effect of the highly educated labour force in the ICT sector.

\section{MICROECONOMIC EFFICIENCY ANALYSIS}

According to the Croatian Chamber of Commerce data, there has been 32248 employees in the ICT sector in Croatia. At the same time, long-term assets of the Croatian ICT were HRK Bill.18 422111 255. This production point lies on the isoquant (production function layer curve) where production amounts to HRK $30314054162^{1}$. Now the question arises whether the combination of inputs led to the minimum costs of production. Knowing the annual average annual wage in the ICT sector in Croatia, HRK 80 101, and the average corporate loans interest rate, $7,79 \%$, it is shown that the minimum costs of this production should have been TC $=$ $4016337797^{2}$. However, the actual costs were HRK 24 002461404 , which means that $83,2 \%$ of the costs of the companies in the ICT sector is not direct result of their business activities and should be reconsidered, at least to some extent.

However, this cost analysis does not tell anything about allocation efficiency. According to the microeconomic theory the production is at its optimal allocation point if the slope of the total cost constraint is tangent to the production function layer curve (isoquant) [19]. Algebraically, this condition states as follows [20]:

$$
M R T S_{K L}=\frac{M P_{K}}{M P_{L}}=\frac{r}{w}
$$

Unfortunately, the slope of the isoquant at the production point $\mathrm{A}$ is 1.2 times larger than the slope of the isocost ${ }^{3}$ (Refer to the Figure 3). It is the proof that the

\footnotetext{
${ }^{1} \hat{Y}\left(18422111255,32248=5372.9 \times 18422111255^{0.396} \times\right.$ $322480.596=30314054162$

$2 \mathrm{TC}=\mathrm{rK}+\mathrm{wL}=0,0778 \times 18422111255+80101 \times 32248$

${ }^{3}$ MRTS $_{K L}=1,164 \times 10^{-6}, \frac{r}{w}=9,713 \times 10^{-7}, \rightarrow \frac{M R T S_{K L}}{r / w}=1,199$
}

input allocation is inefficient [21]. The efficiency would have been attained at either point $\mathrm{C}$ or point $\mathrm{B}$; at the point $\mathrm{C}$ the costs of production would have been identical to those at the production point $\mathrm{A}$, but the production would have been larger (higher isoquant), and at the point $\mathrm{B}$ the production would have been equal to that at the point $A$, but with smaller expenditures. In either way the optimum points lie on the expansion path (the radius vector that passes through points $\mathrm{B}$ and $\mathrm{C}$ ). The difference between $B$ and $C$ show how much could have been produced (C) with the costs in $\mathrm{A}$, but due to the inefficiency production was only B. Hence the efficiency level will be expressed as:

$$
E f=\frac{\overline{O B}}{\overline{O C}} \times 100
$$

The empirical data show that at the point $A$ the obtained isoquant was (6).

$$
L=1.9 \times 10^{11} K^{-0,66515092}
$$

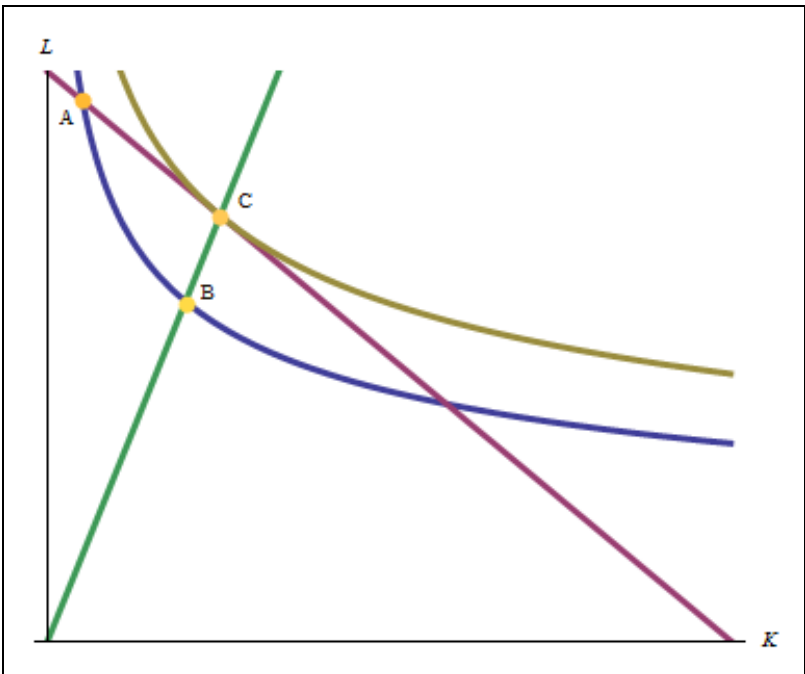

Fig. 3. The actual production equilibrium (A), the same-productionminimum_cost equilibrium (B) and the same-cost-maximumproduction equilibrium $(\mathrm{C})$

However, the empirics also show that having the HRK Bill. 4.0 the ICT sector should have been on the isoquant (7).

$$
L=2.2 \times 10^{11} K^{-0,66515092}
$$

The isocost curve is (8).

$$
L=50140.9-9.7 \times 10^{-7} K
$$

This production equilibrium is shown on the Figure 4. The analysis of the allocation efficiency is made according to the (5) and it is shown that the input allocation efficiency is at $92.6 \%$. In other words, the production could be increased by $8 \%$ without any cost cutting measures, but only by redistributing the production expenditures between the inputs. It is shown that more capital should be used, while employing $10 \%$ less labour and $4 \%$ more capital. Some analyses show 
that in the large companies, according to the revenueprofit managerial theory, managers tend to employ more workers than needed, keeping profits just above the minimum level [27],[28].

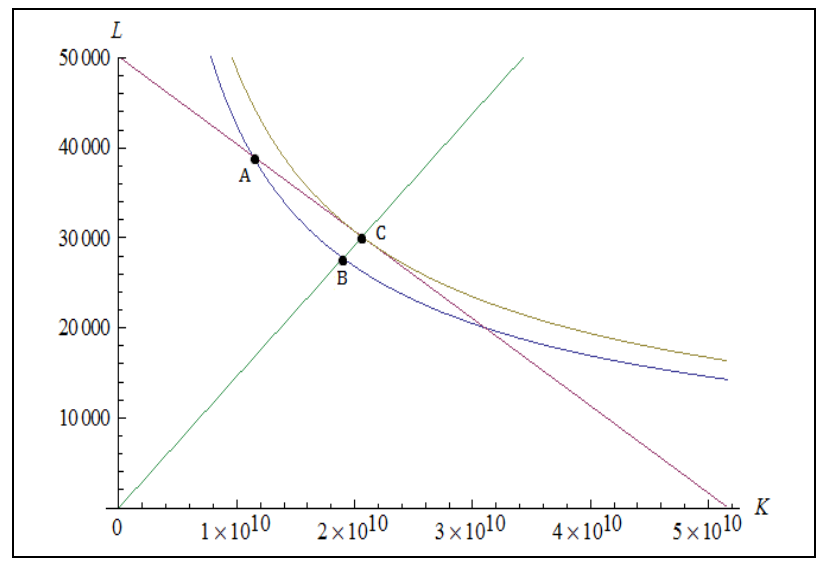

Fig. 4. The actual production equilibrium (A), the same-productionminimum_cost equilibrium (B) and the same-cost-maximumproduction equilibrium (C)

\section{CONCLUSION}

Information and communication sector in Croatia is a very significant market in Croatia since it accounts for $11 \%$ of GDP. However, a question of the allocation efficiency has arisen. The question is: would it be possible to increase the production of the ICT sector without the increase in the invested assets.

The answer to this question may be given using the microeconomic analysis of the production of ICT market. According to the microeconomic theory, a production depends on the amount of capital and labour. Hence the starting point was determination of the production function parameters, using Cobb-Douglas production function.

The analysis has not only provided the exact production function expression for Croatian ICT, but has also enabled the analysis of the marginal rate of technical substitution of the capital and labour (MRTS). By theory, it should be equal to the ratio of the input prices, but it was shown that it was not the case in the Croatian ICT sector, since MRTS is $20 \%$ larger than the rent-wage ratio.

Further analysis of the expansion path of the ICT sector in Croatia has shows that the production of this sector could be improved by $8 \%$ if production expenditures were redistributed from labour expenditures to the investment. Comparing the ICT sector with the other sectors in Croatia, it is evident that ICT is among the most efficient in the input allocation, which is mostly due to the fact that ICT companies are almost exclusively private owned and owned by the foreign investors. However, an $8 \%$ increase in the market which counts its total revenue in billions of kunas, is not insignificant. On the other hand, there are proofs of a systematic tendency to employ more people than needed in the large scale companies [27],[28],[29].

The analysis made in this paper has also shown that the actual costs do not conform to the calculated production expenditure. Moreover, there is a large discrepancy between the former and the latter (six times bigger) which shows that even greater improvements could be made in the cost-cutting in the ICT companies.

To sum up, this paper has shown that (i) labour is more productive than capital in the ICT sector in Croatia, (ii) a somewhat improvement of $8 \%$ could be made in the allocation efficiency if more capital were used, (iii) ICT is among the best allocation efficiencies in Croatian economy, which might be the effect of the foreign private ownership, and (iv) much greater advance could be made if the adequate cost-cutting procedures were conducted.

\section{REFERENCES}

[1] *** (2012) www.dzs.hr (Državni zavod za statistiku), accessed on 2012-08-15

[2] Week, B. .1982. The Reindustrialization of America, Journal of Public and International Research, Princeton University Press, Princeton NJ

[3] Palmero, A., J. H.. 2004. Total Factor Productivity and Growth in Mexican Manufacturing During the Period 1929. - 1944. University of California, Los Angeles

[4] Chen, E. K. Y. 1977. Factor Inputs, Total factor Productivity, and Economic Growth: The Asian Case. The Developing Economies, Vol.15, I.2, p. 121-143

[5] Ackerberg, D. A., K. Caves, G. Frazer. 2006. Structural Identification of Production Functions. (Dec)

[6] Hulten, C.R. 2007. Getting Economic Depreciation Almost Right. Proceedings of the Canberra II Group Symposium, Pariz, 23. 27.4.2007

[7] Hulten, C.R., F.C. Wykoff. Economic Depreciation And Accelerated Depreciation: An Evaluation of the Conable-Jones 10-5-3 Proposal, National Tax Journal, Vol. XXXIV

[8] Becker, G.S. 1964. Human Capital: A Theoretical and Empirical Analysis with Special Reference to Education. Columbia University Press, New York

[9] Labour Force Survey , www.dzs.hr/Hrv/system/first_results.htm, .accessed on 26 August 2012

[10] Bartelsman, E. J. , W. Gray. 1996. The NBER Manufacturing Productivity Database. NBER Technical Working Paper No. 205. (Oct.)

[11] Arezki, R., Cherif, R. 2010. Development Accounting and the Rise of TFP. International Monetary Fund Working Paper 10/101

[12] Aw, B.Y., X. Chen, M. J. Roberts. 2001. Firm-level evidence on productivity differentials and turnover in Taiwanese manufacturing. Journal of Development Economics, Vol. 66, p. 51-86

[13] Bahovec, V. i N. Erjavec (2009). Uvod u ekonometrijsku analizu, Element, Zagreb

[14] Wooldridge, J. M. .2006., Introductory Econometrics: a Modern Approach, 3rd Edition, Thomson South-Western, Mason, Ohio

[15] Bjurek, H. 1996. The Malmquist Total Factor Productivity Index. The Scandinavian Journal of Economics, Vol. 98, No. 2(Jun), pp. 303-313

[16] R.L. Moomaw, R.L., M. Williams. 1991. Total Factor Productivity Growth In Manufacturing Further Evidence From The States. Journal of Regional Science, Vol. 31, Issue 1 (Feb), pages $17-34$

[17] Mansfield, M. 1980. Basic Research and Productivity Increase in Manufacturing. The American Economic Review, Vol. 70, No. 5 (Dec), pp. 863-873

[18] Beeson, P. 1987. Total Factor Productivity Growth And Agglomeration Economies In Manufacturing, 1959-73. Journal of Regional Science, Vol. 27, Issue 2 (May), pp 183-199

[19] Gravelle, H.\&Rees, R. 2004. Microeconomics. 3rd Edition, Prentice Hall, Essex

[20] Chiang, A.C.1994. Osnovne metode matematičke ekonomije. Trece izdanje, MATE, Zagreb, pp.176-178

[21] Berg, A., J.D. Ostry, J. Zettelmeyer. 2008. What Makes Growth Sustained?. IMF Working Paper 08 59, (March) 